\title{
Comparative Study on Awareness of Cervical Cancer among URban AND RURAL WOMEN (30-60 years)
}

\author{
Dr. Alpana Sharma \\ Director, M.M.(P.G.) College, Satikund, \\ Kankhal, Haridwar (UK) \\ Email: dralpanasharma77@gmail.com
}

\begin{abstract}
The cervix is the lower portion of the uterus that connects the uterus to the vagina. The opening of the cervix remains small empty during labor when it expands to allow the baby to pass from the uterus to vagine cervical cancer occurs when a cell in the cervix glow erratically and multiply out of control.

First normal cervical cancer cells change into precancerous cells. Precancerous abnormalities progress without symptoms and if left untreated, they eventually, progress into cancer, when cervical abnormalities are detected and treated in precancerous stages, cervical cancer is preventable.

This study was conducted on 50 rural and urban women (30-60 years). It was carried out in Haridwar using purposive sampling and the questionnaire method was used to obtain information regarding their education cervical cancer.

Results show that majority subjects either urban or rural both are aware about symptoms, signs, prevention, vaccine and other information about cervical cancer. This is because they are modern ladies they were highly educated, they were get more information about cervical cancer by newspaper, internet, magazine, personal communication and other social media.
\end{abstract}

Reference to this paper should be made as follows:

Received: 24.05.2020

Approved: 30.06.2020

Dr. Alpana Sharma

COMPARATIVE STUDY ON AWARENESS OF CERVICAL CANCER AMONG URBAN AND RURAL WOMEN (30-60 $Y E A R S)$

RJPSSs 2020, Vol. XLVI, No. 1, pp. 34-37 Article No.04

\section{Online available at:}

http://rjpsss.anubooks.com/ https://doi.org/10.31995/

rjpsss.2020v46i01.04 
RJPSSs, Vol. XLVI No.1, June 2020 ISSN: (P)0048-7325 (e) 2454-7026 Impact Factor 7.821 (SJIF) https://doi.org/10.31995/rjpsss.2020v46i01.04

\section{Introduction}

A cervix is the lower portion of the uterus that connects to the vagina.The opening of the cervix remains small empty during labor when it expends to allow the body to pass from the uterus to vagina. Cervical cancer occurs when cells in the cervix grow erratically and multiply out of control.

Cervical cancer is a type of cancer that occurs in the cervix the lower part of the uterus the connects to the vagina. Various strains of the human papillomavirus(HPV) a sexually transmitted infectio9n,play a role in causing most cervical cancer.

Arunadevi V. and Geeta Prasad(2015) studied on knowledge and awareness of cervical section interview based survey was conducted in May 2015 to 200 women attending a will women clinic were asked to complete a questionnaire assessing cervical cancer awareness and specific knowledge about prevention of the disease. Result shows that only $38 \%$ of the subject were aware that cervical cancer is the most cause of gynaecological cancers $63 \%$ were aware that infection is the most common cause of cervical cancer $49 \%$ said that virus is the cause and $16 \%$ subjects know that the virus is HPV only 13 out of 200 respondent were aware of HPV vaccine.

Symptoms of cervical cancer-

- Unusual bleeding

- Constipation

- Blood in urine

- Loss of bladder control

- Bone pain

- Swelling of one of legs or caused by swelling in kidneys

- Lost of appetite

- Weight loss

- Tiredness and lake of energy

Postcoital bleeding

\section{Causes of cervical cancer}

HPV (human papillomavirus)

\section{Vaccination}

Girls are affected the childhood immunization programme. The vaccine is given to girls when they are 12-13 years old. 


\section{Objectives of the study}

The main objective of the study is to find out the comparison on awareness of cervical cancer among urban and rural women

\section{Methodology-}

- Area of the study-The study was conducted on 50 women (30-60 years) of haridwar city and village (Jagjeetpur)

- Sampling procedure-The study was conducted on representative groups of 50 women ( 25 urban and 25 rural) in the age range of 30-60 years from haridwar. Purposive sampling technique was used due to shortness of time. General instruction regarding the questionnaire were given and then every respondent interviewed separately and doubts if any were cleared by explaining each and every question to them.

Result-

\section{TABLE 01}

Distribution of respondents on the basis of awareness about cervical cancer.

\begin{tabular}{|c|c|c|c|c|c|}
\hline \multirow{2}{*}{$\begin{array}{c}\text { S. } \\
\text { No. }\end{array}$} & \multirow{2}{*}{ Response } & \multicolumn{2}{|c|}{ Rural women } & \multicolumn{2}{c|}{ Urban women } \\
\cline { 3 - 6 } & & Frequency & Percentage & Frequency & Percentage \\
\hline 1 & Yes & 02 & 08 & 19 & 76 \\
\hline 2 & No & 23 & 92 & 06 & 24 \\
\hline & Total & 25 & 100 & 25 & 100 \\
\hline
\end{tabular}

Result shows that out of total subjects $8 \%$ rural and $76 \%$ urban women aware about cervical cancer.

\section{TABLE 02}

Distribution of respondentsOn the basis of awareness about Preventive vaccine.

\begin{tabular}{|c|c|c|c|c|c|}
\hline \multirow{2}{*}{$\begin{array}{c}\text { S. } \\
\text { No. }\end{array}$} & \multirow{2}{*}{ Response } & \multicolumn{2}{|c|}{ Rural women } & \multicolumn{2}{c|}{ Urban women } \\
\cline { 3 - 6 } & & Frequency & Percentage & \multirow{2}{*}{ Frequency } & Percentage \\
\hline 1 & Yes & 07 & 28 & 20 & 80 \\
\hline 2 & No & 18 & 72 & 05 & 20 \\
\hline & Total & 25 & 100 & 25 & 100 \\
\hline
\end{tabular}

Results shows that out of total subject $28 \%$ rural and $80 \%$ urban women aware about preventive vaccine. 
RJPSSS, Vol. XLVI No.1, June 2020 ISSN: (P)0048-7325 (e) 2454-7026 Impact Factor 7.821 (SJIF) https://doi.org/10.31995/rjpsss.2020v46i01.04

TABLE 03

Distribution of respondents on the basis of awareness about smoking and alcohol as a cause of cervical cancer.

\begin{tabular}{|c|c|c|c|c|c|}
\hline \multirow{2}{*}{$\begin{array}{c}\text { S. } \\
\text { No. }\end{array}$} & \multirow{2}{*}{ Response } & \multicolumn{2}{|c|}{ Rural women } & \multicolumn{2}{c|}{ Urban women } \\
\cline { 3 - 6 } & & Frequency & Percentage & \multirow{2}{*}{ Frequency } & Percentage \\
\hline 1 & Yes & 18 & 72 & 20 & 80 \\
\hline 2 & No & 05 & 20 & 04 & 16 \\
\hline & Don't & 02 & 08 & 01 & 04 \\
\hline & Total & 25 & 100 & 25 & 100 \\
\hline
\end{tabular}

Result shows that $72 \%$ rural and $80 \%$ urban women said that smoking andalcohol is a main cause of cervical cancer only $8 \%$ rural and $4 \%$ urban women didn't know about that.

Conclusion-

The present study was carried out "A comparative study on awareness of cervical cancer among urban and rural women(30-60 years).For this purpose a simple of 50 women ( 25 rural and 25 urban)were selected questionnaire interview framed to collect information on the age,education, dietary habit and awareness about cervical cancer.

$\mathrm{v}$ Majority of subjects i.e.76\% urban women aware about cervical cancer.

$\mathrm{v}$ Majority of subjects i.e. $80 \%$ urban women aware about preventivevaccine of cervical cancer.

Majority of subject i.e. $74 \%$ rural and $80 \%$ urban woman said that smoking and alcohol is a main cause of cervical cancer only $8 \%$ rural and $4 \%$ urban didn't know about that.

Result show that urban and some rural women aware about cervical cancer because they were more educated they get more information about cervical cancer from newspaper, internet,magazine and personal communication. Some rural and urban women were not aware about this because they were neither highly educated nor aware about causes, symptoms and other information aboutthat.Social media plays a significant role in every field I think it will be compulsory for all girls and woman to know about this dangerous disease and for rural development pt will be

\section{Reference}

1. V. Arunadevi, Prasad Geeta(2015), knowledge and awareness of cervical cancer among women in Rural India, Int. J. cw Ra Rev Vol 7, issue 21, Nov 2015 